\title{
Did COVID-19 challenges psychological resilience of pregnant women? an evidence-based review with recommendation
}

\author{
Betsy Chakraborty* \\ College of Nursing, All India Institute of Medical Sciences, Rishikesh, Uttarakhand, India
}

Received: 30 March 2021

Accepted: 30 April 2021

\section{*Correspondence:}

Mrs. Betsy Chakraborty,

E-mail: rollychakraborty@gmail.com

Copyright: $\odot$ the author(s), publisher and licensee Medip Academy. This is an open-access article distributed under the terms of the Creative Commons Attribution Non-Commercial License, which permits unrestricted non-commercial use, distribution, and reproduction in any medium, provided the original work is properly cited.

\begin{abstract}
Any conflict, extreme stress, emergency situation, natural disaster multiplies mental health hazard. History of Spanish flu outbreak witnesses the damage of pregnant women i.e. as short-term impact inflate the rate of preterm deliveries and the baby's who were in womb persist the risk of developing medical and psychiatric disorders like diabetes, coronary artery disease, cancer and schizophrenia in future. Pregnant women are considered more vulnerable for COVID-19 as pregnancy makes women prone to respiratory pathogen, which leads to severe pneumonia. Women are three times more prone to anxiety than man. Continuous strict restriction on consultancy visit and gathering, rumors and contradictory information, uncertainty about delivery plan \& health of mother and baby indirectly affected women's emotional and psychological health of perinatal period. Fear and stigma grasps them when anticipating social discrimination and segregation from baby if they become positive. Growing evidence shows psychological impacts i.e. high levels of anxiety, depression and stress are prevalent among pregnant women irrespective of geographical and cultural boundaries across countries like India, China, Canada, UK, Australia and Israel. WHO recommended for adopting holistic approach of care, consideration of major two aspects (i.e. clinical and psychological experiences) in pandemic situations for helping in better positive coping of mother, baby and family members. This present review aimed to find out triggering factors, challenges, major types of psychological issues, consequences of psychological impact among perinatal women due to COVID-19 and want to prescribe evidence-based resolution and preparedness for combating such pandemic situation.
\end{abstract}

Keywords: COVID-19, Perinatal period, Psychological impact, Anxiety, Depression, Stress

\section{INTRODUCTION}

Since December 2019, after the first announced case of a very new and genetically modified viral respiratory disease in Wuhan, china catches every country's attention slowly. WHO labelled this disorder as novel corona virus disease and the causative agent was severe acute respiratory syndrome coronavirus 2 (SARS-CoV-2). ${ }^{1}$ The speed of spreading of this highly contagious fetal disease which had apparently no treatment modalities and no cure, very quickly increases the burden of new cases and death number. $^{2}$ On 12 March 2020, WHO declared this unmanageable outbreak as pandemic and considered as public health emergency of International concern (PHEIC) and 22 May 2020 onwards scrutinizing for community transmission started. ${ }^{3,4}$ Till now there are 116,135,492 confirmed cases and it snatches 2,581,976 lives worldwide and in India 11,210,799 is the victims number and 157,756 is the death number as per WHO and Ministry of Health and family welfare (Government of India) official website. $^{5}$

Pregnancy is considered as a special vulnerable group because this group goes through tremendous physical, physiological and psychological challenges, more accurately hormones like estrogen, progesterone levels increases very high and their immune-tolerance status converted their immunity in hypo status which makes women more susceptible for upper respiratory viral infection such as severe acute respiratory syndrome 
(SARS), Middle East respiratory syndrome (MERS) and influenza. ${ }^{6}$ Not only that existing research evidence shows that whole perinatal period is roller coaster ride and summoning changing role, worries regarding baby's wellbeing and delivery, sleep issues, relationship issues, lonely feelings, ambiguous feelings, psychiatric disorder (i.e. anxiety, mood disorder). ${ }^{7}$ WHO also do agree with the fact that during pregnancy and followed by one year women may experience mental disorders. ${ }^{8}$

Prevalence rate of depression during peri-natal period though out the world is $10 \%$, during pre-natal period is $12 \%$, during postpartum is $17 \%$, in developing countries during pregnancy is $15.6 \%$ and after delivery rises to $19.8 \%$, gestational anxiety level is $15-23 \%$ whereas $3-5 \%$ normally found in general population. ${ }^{9-11}$ Among every seven women one became the sufferer of anxiety or depression during perinatal period. ${ }^{12} 22 \%$ Indian mother manifest the symptoms of puerperal blue. ${ }^{13}$

Despite of all these issues, this new transition brings new hope, positive vibes and happy beginning of parenthood but this catastrophic pandemic situation pushed all joy into extreme level of stress, worry, conflict and poor maternal and child health outcome. ${ }^{8,14}$ This wide range of negative emotion amplified the normal prevalence rate of perinatal mental health disorder. ${ }^{15}$ To protect two most necessary millennium development goals i.e. maternal and child health need to boost mental health of would be mother. ${ }^{8}$

\section{METHODS}

Review author searched pubmed, medline, embase, ovid, scopus, google scholar search engine from 2019 to 2021 (last search 28 February 2021) and extracted with keywords, free text terms and MeSH terms such as 'perinatal period'and 'pandemic' and 'psychological impact' and 'psychological resilience'.

\section{Psychological impact}

Recent multiple research evidence talks about that pregnant women informed poor psychological well-being and there is lacking of level of resilience like before the pandemic time (Table 1).

Multiple potential factors identified which causes psychological issues \& negative consequences (Table 2) and pregnant mother and health care worker faced so many challenges (Table 3). Psychological impact majorly could be grouped under following:

Worry

93\% pregnant women own a positive attitude towards following every Government guideline (quarantine, social distancing) sincerely but there were conflict persisting among the sources of information. Study done by Mappa et al in Italy revealed that $64 \%$ acquiring information from newspaper and television, 29\% from internet and social media but only $7 \%$ got valid information from health care personnel in contrast 37\% worried for not having information regarding how does COVID-19 effects pregnancy. ${ }^{3}$ An online survey data identified the reason of worrying were $83.1 \%$ for 'potential infected people were unprotected and non-isolated', 78.6\% for 'self-infection could affect the health of their baby', and $56.2 \%$ for 'they themselves becoming infected and being isolated' ${ }^{23}$

\section{Fear}

Fear existing in their mind because they were scare of the thought that it might affect peri-natal health and Mappa et al mentioned in result section that more than 50\% suffer from rumination of thought like poor fetal outcome in terms of preterm delivery, fatal anomaly, growth restriction tough they have anomaly scan in their hand, after delivery might be early segregation of baby from the mother. $75 \%$ persisting fear to attend regular hospital visits on the other hand $37 \%$ feels uneasy for not able to continue proper antenatal care. $22 \%$ women are actually frightened for coming contact with the virus. ${ }^{3,9}$

Stress

Stress multiplies in this pandemic situation due to uncertainty of antenatal and postnatal care, delivery plan, less face to face regular visits to consultant, new protocol, new way of extended health services like tele-health concept, clinical infrastructure, referral system, duration of present scenario, perceived threat on maternal and child health even the health of dear ones which is beyond actual control, chances of exposure and consequences, perceiving that lack of chances of getting husband's presence during delivery and family support system. ${ }^{9}$

Evolutionary point of view explained that if mother exposed to acute life-threatening levels of stress throughout the pregnancy, the child within the womb also fight to adjust with the same and may resultant negative consequences like Attention deficit hyperactivity disorder. Alike higher vigilance associated with anxiety disorder and moreover she might show dissociative symptoms. ${ }^{24}$

\section{Feelings of anger, frustration and loneliness}

Negative emotions grasps them when they are thinking there will be very less social and family caregiver support network, are not allowed to roam in the park for walk, can't mingle with society members or near and dear ones. ${ }^{9}$

\section{Mood disorder}

Quantitative study findings done by Luca DL in US reports that pandemic situation increases the amount of mood disorder rate among pregnant and postnatal women. ${ }^{25}$ 


\section{Anxiety}

In Colorado state of US findings proves that peri-natal anxiety rate literally became six times higher in pandemic situation than pre-pandemic time. ${ }^{25}$ A nationwide survey for digging anxiety among pregnant women during pandemic in USA indicate that they are definitely anxious for being pregnant during this time but anxiety score is more-high with the thought of baby birth in this acute stage..$^{15}$

\section{Intimate partner violence/domestic violence}

Persisting of pandemic and lockdown condition for a long time grossly affected global economy, family income (specifically low and medium socio-economic families) and all immigrant population affected deep rooted. In current scenario home environment also precipitating stress mainly for financial crisis due to loss of job, as a consequences bread winner choosing wrong path for coping like substance abuse or suicide, long time confinement of pregnant women with spouse and whole family members together as work from home going on, lack of independency, elderly people's more expectation for care, presence of young children due to long leave of school, less opportunity for getting needed services and goods due to lockdown. ${ }^{9,26}$ These all harvested the seeds for misunderstanding; gender based violence and actually increases the incidence of domestic violence $300 \%{ }^{27}$

\section{Toxic stress, self-blame and shame}

Protocol like segregating baby from mother immediate after birth during this period produces consequences like too early cessation of breastfeeding and mother became victims of toxic stress or matter of self-blame and shame. ${ }^{8}$

\section{Post-traumatic stress disorder}

Different strict infection control protocol like patient isolation, quarantine period, corona test prior admission, dealing with emergency normal delivery with proper personal protective equipment and with the same protocol like corona positive patient as the corona test result is pending, these all situations adding the risk of posttraumatic stress disorder. ${ }^{28}$

\section{Other effects}

National population based research bring us the evidence that $34.3 \%$ pregnant women and baby face the pregnancy related complication namely low birth weight. ${ }^{29}$ Retrospective review showed direct effect on nine mothers who suffered from COVID-19 pneumonia in last trimester, almost $50 \%$ delivered early. ${ }^{30}$ Long time stress pushed the mother in the lap of nausea, vomiting, preterm delivery, pre-eclampsia, depression and the baby to low Apgar score. ${ }^{14}$ Incidence reported more than $2 \%$ ectopic pregnancy and congenital disabilities or genetic disorders among 3-5\% pregnancies. $^{17}$
Hospital delivery rates fall from $96.4 \%$ to $87.7 \%$. Elective caesarean delivery rate accelerates upto $16.7 \%$ which was previously $5-10 \% .{ }^{15}$ Majorly most of the hospital converted as COVID-19 or else they are treating COVID-19 patient free of cost. Afraid of this situation pregnant women were running for maternity hospital where they are taking care of only pregnant women and for all the mandatory vaccination, iron and folic acid supplement, regular weight and BP checking or for much needed test they chosen family health centre. ${ }^{22}$ Opting for home delivery might increase the chance of maternal and neonatal mortality due to lack of availability of professional health personnel. ${ }^{26}$

COVID-19 positive, frightened mother often chooses not to breast feed. ${ }^{26}$

COVID-19 forced mothers to accept alternatives of regular antenatal visits. $25.8 \%$ reported that they stopped visits, $15.2 \%$ started video visits and $31.8 \%$ continues through phone calls. ${ }^{15}$

Hampered daily routine for working and nonworking women and reduces physical activity even evening or morning walk also less due to restriction. ${ }^{22}$

Immediate after the outbreak in China news spreads that COVID-19 and pregnancy time infection or morbidity is not related but when it converted as global pandemic data like more preterm deliveries, maternal and neonatal mortalities, presence of severe acute respiratory syndrome coronavirus-2 (SARS-COV-2) in second trimester placenta found and unpredictable situation rise the thought and incidence of pregnancy termination. ${ }^{26}$ Texas is banning abortion as a non-essential operation this news also came in headline during this crisis period. ${ }^{8}$

\section{Intervention}

The women who are already threatened, not enough confident, does not possess preventive knowledge, continuing job in different sector specially in bank, police or health care delivery system with pregnancy, became COVID-19 positive with pregnancy need extra attention and care. ${ }^{2}$

The summarization of existing literature evidences recognizes few themes and subthemes for intervention and recommendations.

\section{Theme I: Strengthening positive coping and restoring positive mental health}

Recognizing the possible positive factors, practicing positive coping strategies, changing their perspective of expectation and promoting positive mental health can protect the emotional health of the pregnant women during the pandemic situation. Most of the pregnant women identified different ways to divert their mind with positive thoughts like they kept themselves busy with proper care of own-self by focusing on nutritional diet, ample of sleep, 
balanced activity. Few of them claimed that adherence to routine schedule is helpful. Spending time with partner, family members even with friends through virtual platform or in reality during lockdown period both accepted as supportive. Practice like roaming in the park by maintaining needed distance, listening to her most favourite song, be connected with the other pregnant women or new moms virtually, cultivating hobbies, habit of writing daily dairy, gratitude for getting family special time, meditation like mindfulness, different relaxation exercises, collection of proper information regarding safety during this period can boost the optimism. $3,9,17,15$ Chen et al noted that $80.17 \%$ pregnant women relied on self-entertainment activities (like watching movies, listening music or reading books) and $71.38 \%$ occupied them in chatting with near and dear ones. ${ }^{17}$ Sahin, Kabakci found that few pregnant women stay aloof from watching $\mathrm{TV}$ or news to allay anxiety levels. ${ }^{22}$

\section{Theme II: Restructuring the existing treatment policy}

Gynaecological and mid-wives consideration

Genuine need to start telehealth consultation services and minimum face to face visits which is necessary to minimize the rate of exposure, using of 'Arogya Setu' app for better tracking. ${ }^{18}$ Provision for isolation ward or different set up for emergency services, visitor restriction and well-designed area as well as protocol for COVID-19 test and treatment should be chalk out proactively. ${ }^{22}$ Infection control department should extend their hands to help every department for awareness and monitoring smooth utilization of necessary protective kits and procedures. The consultant and the staff who are looking after mother, they should be solely responsible for that only, not to be included in care of COVID-19 patient. If mothers are positive, different staff should be allocated with proper protection and quarantine.

Detail screening in every visit, identifying the high-risk group of mood alteration among pregnant women and dealing with emotional responses during postpartum period is the most crucial role of immediate midwives and the gynaecologist because due to lockdown most of them have less family support and in different settings they are not even allowed to be with the new mother. Lactation consultant and paediatrician should be present after child birth. Intensify the pregnant women's and family member's trust and sense of security by providing accurate information and knowledge.

Study shows that pregnant women are more dependent on their consultant for any information regarding COVID-19 as they explained that information from different media source are very much contradictory. Gynaecology dept need to arrange awareness campaign focusing on protection concern through virtual platform, telehealth or by distributing handouts. ${ }^{14}$
Go with WHO guidelines i.e. mother and baby should be in the same room even mother is COVID-19 positive but during breastfeeding respiratory etiquettes like hand hygiene, wearing a mask is mandatory. ${ }^{8}$

\section{Mental health consideration}

Tough psychological issues are too common during pregnancy but only $7 \%$ seek professional help, another study claim it is $4.48 \% .^{3,17}$ But after finding any emotional or psychological issues pregnant women should be referred then and there for professional counselling during this pandemic situation. Screening can be done through internet-based screening tools and counselling through telehealth services, toll free number, web based psychological session. ${ }^{26}$ Studies recommended that virtual training session, webinar or apps regarding how to cope with anxiety, low mood may be beneficial. ${ }^{22,28}$

\section{Theme III: Special consideration needed in organizational policy}

Female pregnant women should get vulnerable status and special consideration during this period. Organization can provide the facility like work from home or isolated work place to minimize the chance of infection and support for postnatal excusive breast feeding.

\section{Theme IV: Improve spiritual health}

Very recent studies assert that exploring and believe on own spiritual core have positive effects on mental health also. $^{31}$

\section{Theme V: Vaccination}

Till now 2,09,89,010 people got vaccinated in India but pregnancy and lactation period is excluded from the COVID-19 vaccination drive and labelled as contraindication. ${ }^{5}$

Already published literature outlined that pregnant women who became COVID-19 positive exhibits similar symptoms like non pregnant group, moreover it was not in severe form and even few remain asymptomatic. ${ }^{17}$ No confirmed evidence found from the existing studies about vertical transmission, transmission during delivery (normal or caesarean section), during breastfeeding and no trace of virus detected in amniotic fluid or throat swab of the babies. ${ }^{8}$ Few researchers pointed out that children group has less risk of getting infection and worse adverse effect like adult. ${ }^{32}$

Health care team and family member together need to work on replacing all those negative emotion with positive thoughts then only their awareness will be broadened and there will be place for needed action instead of rumination of negative thought, alike the broaden-and-build theory suggest. ${ }^{33}$ 
Table 1: Evidences regarding psychological impact on pregnant women due to COVID-19.

\begin{tabular}{|c|c|c|c|}
\hline Study characteristics & Participants & Country & Results \\
\hline $\begin{array}{l}\text { Khatri et al } \\
\text { Cross-sectional } \\
\text { observational study }\end{array}$ & $\begin{array}{l}98 \text { pregnant } \\
\text { women }\end{array}$ & $\begin{array}{l}\text { Tertiary setting } \\
\text { in Mumbai, India }\end{array}$ & $\begin{array}{l}72.2 \% \text { talk about moderate level of stress, } 51.6 \% \\
\text { about mild to moderate depression, } 39.4 \% \text { about } \\
\text { mild to moderate anxiety. } 39.4 \% \text { expressed their } \\
\text { worry for their babies might get infection and } \\
25.8 \% \text { for their own risk of infection. }\end{array}$ \\
\hline $\begin{array}{l}\text { Farewell et al } \\
\text { Online survey }\end{array}$ & $\begin{array}{l}31 \text { pregnant and } \\
\text { postnatal } \\
\text { mothers }\end{array}$ & USA & $\begin{array}{l}12 \% \text { are victim of high level of depression whereas } \\
60 \% \text { reported moderate or severe level and } 40 \% \\
\text { complains of being lonely. }\end{array}$ \\
\hline $\begin{array}{l}\text { Chen et al } \\
\text { Web based survey }\end{array}$ & $\begin{array}{l}1160 \text { pregnant } \\
\text { women }\end{array}$ & China & $\begin{array}{l}\text { Age over } 30 \text { years, junior college level education } \\
\text { and last trimester of pregnancy are the major } \\
\text { victim. }\end{array}$ \\
\hline $\begin{array}{l}\text { Berthelot et al } \\
\text { Longitudinal study }\end{array}$ & $\begin{array}{l}1754 \text { pregnant } \\
\text { women }\end{array}$ & Quebec, Canada & $\begin{array}{l}\text { Severe depression, anxiety, more negative } \\
\text { affectivity, symptoms of PTSD and dissociation } \\
\text { also present in pregnant cohort group during the } \\
\text { pandemic. }\end{array}$ \\
\hline $\begin{array}{l}\text { Taubman et al } \\
\text { Comparative study }\end{array}$ & $\begin{array}{l}336 \text { Israeli } \\
\text { Jewish and Arab } \\
\text { pregnant women } \\
\text { aged } 20-47\end{array}$ & Israel & $\begin{array}{l}\text { Jewish pregnant women exhibit psychological } \\
\text { stress more than Arab pregnant women. }\end{array}$ \\
\hline $\begin{array}{l}\text { Salehi et al } \\
\text { Cross-sectional study }\end{array}$ & $\begin{array}{l}222 \text { pregnant } \\
\text { women }\end{array}$ & Iran & $\begin{array}{l}\text { Anxiety of COVID-19 and concerns during } \\
\text { pregnancy and fear of COVID } 19 \text { and Concerns } \\
\text { of pregnancy experiences are positively } \\
\text { correlated with mental health but happiness and } \\
\text { pregnancy experiences has negative correlation } \\
\text { with mental health disorder. }\end{array}$ \\
\hline $\begin{array}{l}\text { Wong et al } \\
\text { Cross-sectional survey }\end{array}$ & $\begin{array}{l}1210 \text { pregnant } \\
\text { women }\end{array}$ & $\begin{array}{l}194 \text { cities of } \\
\text { china }\end{array}$ & $\begin{array}{l}53.8 \% \text { suffers psychologically whereas } 28.8 \% \\
\text { and } 16.5 \% \text { had moderate to severe anxiety and } \\
\text { depression respectively. }\end{array}$ \\
\hline $\begin{array}{l}\text { Davenport et al } \\
\text { Online rapid response } \\
\text { survey }\end{array}$ & $\begin{array}{l}900 \text { eligible } \\
\text { women }\end{array}$ & Canada & $\begin{array}{l}\text { Presence of high anxiety }(72 \%) \text { and depression } \\
(40.7 \%) \text { in pregnant women and they said that } \\
\text { isolation decreased physical activity in } 64 \% \\
\text { women but } 150 \text { minutes moderate amount of } \\
\text { physical activity lessen the chance of anxiety and } \\
\text { depression. }\end{array}$ \\
\hline $\begin{array}{l}\text { Zhou et al } \\
\text { Cross-sectional study }\end{array}$ & $\begin{array}{l}859 \text { pregnant } \\
\text { and non- } \\
\text { pregnant } \\
\text { women }\end{array}$ & China & $\begin{array}{l}5.3 \% \text { have depression, } 6.8 \% \text { anxiety symptoms } \\
\text { present, } 2.4 \% \text { suffer from physical discomfort, } \\
2.6 \% \text { from insomnia and } 0.9 \% \text { have PTSD. }\end{array}$ \\
\hline $\begin{array}{l}\text { Qi et al } \\
\text { Cross-sectional } \\
\text { mixed-method study }\end{array}$ & $\begin{array}{l}303 \text { pregnant } \\
\text { women }\end{array}$ & China & $\begin{array}{l}\text { Threaten and non-confident cluster manifest } \\
\text { disorders such as depression, anxiety, } \\
\text { neurasthenia in contrast with unthreatened, } \\
\text { confident cluster. }\end{array}$ \\
\hline $\begin{array}{l}\text { Sahin et al } \\
\text { Qualitative study }\end{array}$ & $\begin{array}{l}15 \text { pregnant } \\
\text { women }\end{array}$ & Turkey & $\begin{array}{l}\text { Corona virus is significantly capable for } \\
\text { producing anxiety, fear, adversity and all these } \\
\text { will be ended up with enhancing negative } \\
\text { emotional health of pandemic time pregnant } \\
\text { mother and will be hunted by postpartum } \\
\text { depression in near future. }\end{array}$ \\
\hline
\end{tabular}


Table 2: Causes and consequences behind psychological issues among pregnant women during COVID-19.

\begin{tabular}{|c|c|c|}
\hline Triggering factors and protective factors & Psychological impact & Possible negative consequences \\
\hline Triggering factors & & Maternal effects \\
\hline \multirow{3}{*}{$\begin{array}{l}\text { Demographic factors- age ( } 18-30 \text { years), lower } \\
\text { education level, poor immunity in } 1^{\text {st }} \text { trimester, } \\
\text { migrant population. } .^{17}\end{array}$} & \multirow{2}{*}{ Poor well-being and resilience. ${ }^{9}$} & Impaired psychosocial function $^{18}$ \\
\hline & & Infection of COVID- 19 \\
\hline & \multirow{3}{*}{$\begin{array}{l}\text { Unpleasant psychological } \\
\text { outcome (i.e., feeling of } \\
\text { loneliness, isolated, } \\
\text { worrying). }{ }^{3,9}\end{array}$} & $\begin{array}{l}\text { Probability of suffering from } \\
\text { pneumonia }^{21}\end{array}$ \\
\hline Emergency and conflict situation. $^{8}$ & & Nausea and vomiting ${ }^{14}$ \\
\hline \multirow{3}{*}{$\begin{array}{l}\text { Lockdown and scarcity of necessary possessions } \\
\text { and services. }{ }^{31}\end{array}$} & & Preeclampsia $^{14}$ \\
\hline & Fear $^{3,9}$ & Maternal morbidity ${ }^{14}$ \\
\hline & Anxiety ${ }^{15,25}$ & \multirow{2}{*}{$\begin{array}{l}\text { Increase the rate of caesarian } \\
\text { delivery }{ }^{15}\end{array}$} \\
\hline \multirow{3}{*}{ Quarantine and social isolation. ${ }^{26}$} & \multirow{2}{*}{ Anger ${ }^{9}$} & \\
\hline & & Thought of home delivery ${ }^{28}$ \\
\hline & Stress \& toxic stress ${ }^{8}$ & Challenging parenting ${ }^{18}$ \\
\hline \multirow{3}{*}{$\begin{array}{l}\text { Lack of spouse, family and social support } \\
\text { during perinatal period and specifically in time } \\
\text { of delivery. }\end{array}$} & Self blame ${ }^{8}$ & \\
\hline & Decisional conflict ${ }^{22}$ & \\
\hline & $\begin{array}{l}\text { Mood disorder (low mood, } \\
\text { depression) }\end{array}$ & \\
\hline Impaired regular routine. ${ }^{8}$ & Postpartum depression $^{22}$ & \\
\hline Reduced daily physical activity. ${ }^{22}$ & Domestic violence $^{9}$ & \\
\hline Lack of information about delivery process. ${ }^{9}$ & Dissociative symptoms ${ }^{2}$ & \\
\hline $\begin{array}{l}\text { No clear-cut guidelines and information from } \\
\text { the hospital. }{ }^{9}\end{array}$ & \multirow{9}{*}{$\begin{array}{l}\text { Post-traumatic stress } \\
\text { disorder }^{28}\end{array}$} & \\
\hline Lack of knowledge and rumors. ${ }^{10}$ & & \\
\hline $\begin{array}{l}\text { Risk of getting infection and uncertainty related } \\
\text { to antenatal visits, delivery time and postnatal } \\
\text { visits. }{ }^{9}\end{array}$ & & \\
\hline Less satisfaction with telemedicine services. ${ }^{9}$ & & \\
\hline $\begin{array}{l}\text { Thought of negative fetal and maternal } \\
\text { outcome. }{ }^{18}\end{array}$ & & \\
\hline Lack of scope for the mandatory anomaly scan. & & \\
\hline \multirow{2}{*}{$\begin{array}{l}\text { Visitor restriction during delivery vis-à-vis lack } \\
\text { of postpartum family support. }{ }^{26}\end{array}$} & & Fetus effects \\
\hline & & Abortion $^{26}$ \\
\hline \multirow{2}{*}{$\begin{array}{l}\text { Isolation from new born after delivery for } \\
\text { COVID- } 19 \text { positive mother. }{ }^{8}\end{array}$} & & Preterm delivery ${ }^{14}$ \\
\hline & & Low birth weight ${ }^{14}$ \\
\hline \multirow{3}{*}{$\begin{array}{l}\text { Tension regarding selecting hospital for delivery } \\
\text { and type of delivery. }{ }^{15}\end{array}$} & & Impaired growth $^{14}$ \\
\hline & & Low Apgar score ${ }^{14}$ \\
\hline & & Impaired brain development ${ }^{18}$ \\
\hline \multirow{3}{*}{$\begin{array}{l}\text { Difficulty in getting ambulance on time due to } \\
\text { most of the ambulance taken for COVID-19 } \\
\text { duty. }\end{array}$} & & $\begin{array}{l}\text { Impaired cognitive } \\
\text { development }^{18}\end{array}$ \\
\hline & & Rise unborn mortality rate ${ }^{26}$ \\
\hline & & $\begin{array}{l}\text { Chance of psychopathology in } \\
\text { future i.e., schizophrenia. }{ }^{18}\end{array}$ \\
\hline $\begin{array}{l}\text { Lack of opportunity for house maid and day } \\
\text { care services. }{ }^{8}\end{array}$ & & \multirow{2}{*}{$\begin{array}{l}\text { Isolation from mother even } \\
\text { cessation of breast feeding if } \\
\text { mother is positive. }\end{array}$} \\
\hline \multirow{2}{*}{$\begin{array}{l}\text { Losing of Jobs vis-a vis financial crisis even } \\
\text { global financial crisis. }{ }^{26}\end{array}$} & & \\
\hline & & \\
\hline
\end{tabular}




\begin{tabular}{|c|c|c|}
\hline Triggering factors and protective factors & Psychological impact & Possible negative consequences \\
\hline $\begin{array}{l}\text { Increase rate of substance abuse by the bread } \\
\text { winner of the family. }{ }^{26}\end{array}$ & & \multirow{4}{*}{$\begin{array}{l}\text { Hampered normal mother child } \\
\text { bonding }^{8}\end{array}$} \\
\hline Increase the rate of suicide among bread winner. & & \\
\hline Decrease sense of security. & & \\
\hline $\begin{array}{l}\text { Extra burden of taking care of elder children as } \\
\text { the schools were closed. }{ }^{26}\end{array}$ & & \\
\hline Living with infected family member. ${ }^{8}$ & & $\begin{array}{l}\text { ADHD and anxiety disorder in } \\
\text { later life. }\end{array}$ \\
\hline Protective factors & & \\
\hline Presence of spouse ${ }^{23}$ & & \\
\hline Work from home facility ${ }^{23}$ & & \\
\hline Sense of security ${ }^{23}$ & & \\
\hline Positive coping mechanism & & \\
\hline
\end{tabular}

Table 3: Major challenges faced by health care professionals and pregnant women during COVID-19.

\begin{tabular}{|c|c|}
\hline Health care professionals ${ }^{28}$ & Pregnant women \\
\hline $\begin{array}{l}\text { Professionals preparing new policy, structure and } \\
\text { protocol. }\end{array}$ & $\begin{array}{l}\text { Extreme strictness on following guidelines of } \\
\text { COVID-19 to allay every single chance of getting } \\
\text { the infection is hard job. }\end{array}$ \\
\hline To force everyone to adhere the rules and guidelines. & $\begin{array}{l}\text { To provide extra effort for must needed laboratory } \\
\text { test and USG. }{ }^{28}\end{array}$ \\
\hline $\begin{array}{l}\text { Resource management for infection control, isolation, } \\
\text { quarantine. }\end{array}$ & Suffering from financial crisis. ${ }^{26}$ \\
\hline $\begin{array}{l}\text { They are becoming victim of patient and family } \\
\text { member's frustration when they tried to be strict } \\
\text { regarding protocol and infection control policy. }\end{array}$ & $\begin{array}{l}\text { Working women are at high risk and if they are in } \\
\text { health care delivery system then they are real } \\
\text { victim. }\end{array}$ \\
\hline $\begin{array}{l}\text { Arrangements of vigorous in-service education } \\
\text { program for different levels of health care } \\
\text { professionals on urgent basis. }\end{array}$ & Less availability of household maid. ${ }^{26}$ \\
\hline $\begin{array}{l}\text { Supplementary training on stress and coping } \\
\text { strategies became mandatory for every gynecological } \\
\text { consultant. }\end{array}$ & $\begin{array}{l}\text { More engagement in cleaning all article and hand } \\
\text { washing. }\end{array}$ \\
\hline
\end{tabular}

\section{CONCLUSION}

This sudden and persisting outbreak passively and actively inserted all negative emotion in pregnant women's mind for self-protection. Every pandemic situation or natural disaster need proactive preparedness and always mental health care professionals should be included in the team.

Funding: No funding sources

Conflict of interest: None declared

Ethical approval: Not required

\section{REFERENCES}

1. Nodoushan RJ, Alimoradi H, Nazari M. Spiritual Health and Stress in Pregnant Women During the Covid-19 Pandemic. SN Compr Clin Med. 2020:1-7.

2. Qi M, Li X, Liu S, Li Y, Huang W. Impact of the COVID-19 epidemic on patterns of pregnant women's perception of threat and its relationship to mental state: A latent class analysis. PLoS One. 2020;15(10):239697.
3. Mappa I, Distefano FA, Rizzo G. Effects of coronavirus 19 pandemic on maternal anxiety during pregnancy: a prospectic observational study. J Perinat Med. 2020;48(6):545-50.

4. WHO. Coronavirus disease (COVID-19) Situation Report-123, 2020. Available at: https://www.icao.int/Security/COVID-19/

EBandSL/eb027e.pdf. Accessed on 23 May 2020.

5. WHO. WHO corona virus (COVID-19) dashboard, 2021. Available at: https://covid19.who.int/. Accessed on 8 March 2021.

6. Ali NA, Shahil FA. Maternal mental health amidst the COVID-19 pandemic. Asian J Psychiatr. 2020;54:102261.

7. WHO. Maternal mental health, 2020. Available at: https://www.who.int/mental_health/maternalchild/m aternal_mental_health/en/. Accessed on 30 March, 2020.

8. Topalidou A, Thomson G, Downe S. COVID-19 and maternal mental health: Are we getting the balance right?. Lancet 2020;7(4):15-6.

9. Farewell CV, Jewell J, Walls J, Leiferman JA. A Mixed-Methods Pilot Study of Perinatal Risk and 
Resilience During COVID-19. J Prim Care Community Health. 2020;11:74.

10. Kajdy A, Feduniw S, Ajdacka U, Modzelewski J, Baranowska B, Sys D, et al. Risk factors for anxiety and depression among pregnant women during the COVID-19 pandemic: A web-based cross-sectional survey. Medicine (Baltimore). 2020;99(30):21279.

11. Woody CA, Ferrari AJ, Siskind DJ, Whiteford HA, Harris MG. A systematic review and meta-regression of the preva- lence and incidence of perinatal depression. J Affect Disord. 2017;2(19):86-92.

12. Davenport MH, Meyer S, Meah VL, Strynadka MC, Khurana R. Moms Are Not OK: COVID-19 and Maternal Mental Health. Maternal Mental Health. Front Glob Womens Health. 2020;1(1):1-6.

13. Ghosh A, Sarkar S. The coronavirus (COVID-19) pandemic's impact on maternal mental health and questionable healthcare services in rural India. Int $\mathbf{J}$ Health Plann Manag. 2020;35(6):1626-8.

14. Salehi L, Rahimzadeh M, Molaei E, Zaheri H, Esmaelzadeh SS. The relationship among fear and anxiety of COVID-19, pregnancy experience, and mental health disorder in pregnant women: A structural equation model. Brain Behav. 2020;10(11): 1835 .

15. Moyer CA, Compton SD, Kaselitz E, Muzik M. Pregnancy-related anxiety during COVID-19: a nationwide survey of 2740 pregnant women. Arch Womens Ment Health. 2020;23(6):757-65.

16. Khatri S, Murthy SCAK, Hashim SCU, Kuruthukulangara CS, Kumari A, Lele CPR. Psychological status of pregnant women during COVID 19 Pandemic: A cross sectional study from Mumbai. J of marine medical society. 2020;22(1): 114-7.

17. Chen S, Zhuang J, Chen Q, Tan X. Psychological Investigation on Pregnant Women During The Outbreak of COVID 19. Res Square. 2020;1-17.

18. Berthelot N, Lemieux R, Garon BJ, Drouin MC, Martel É, Maziade M. Uptrend in distress and psychiatric symptomatology in pregnant women during the coronavirus disease 2019 pandemic. Acta Obstet Gynecol Scand. 2020;99(7):848-55.

19. Taubman BAO, Chasson M, Abu SS, Weiss E. Distress and anxiety associated with COVID-19 among Jewish and Arab pregnant women in Israel. J Reprod Infant Psychol. 2020;38(3):340-8.

20. Wang C, Pan R, Wan X, Tan Y, Xu L, Ho CS, et al. Immediate Psychological Responses and Associated Factors during the Initial Stage of the 2019 Coronavirus Disease (COVID-19) Epidemic among the General Population in China. Int J Environ Res Public Health. 2020;17(5):1729.

21. Zhou Y, Shi H, Liu Z, Peng S, Wang R, Qi L, et al. The prevalence of psychiatric symptoms of pregnant and non-pregnant women during the COVID-19 epidemic Transl Psychiatry. 2020;10(1):319.
22. Mizrak SB, Kabakci EN. The experiences of pregnant women during the COVID-19 pandemic in Turkey: A qualitative study. Women Birth. 2021;34(2):162-9.

23. Qing XZ, Xiu MJ, Yan LRN, Gui HL, Yu PL, Yu LK, et al. The influence of psychological response and security sense on pregnancy stress during the outbreak of coronavirus disease 2019: A mediating model. J of Clinical Nurs. 2020;29:4248-52.

24. Glover V. Annual Research Review: Prenatal stress and the origins of psychopathology: an evolutionary perspective. J Child Psychol Psychiatry. 2011;52(4):356-67.

25. Hughes ME, Waite LJ, Hawkley LC, Cacioppo JT. A Short Scale for Measuring Loneliness in Large Surveys: Results From Two Population-Based Studies. Res Aging. 2004;26(6):655-72.

26. Thapa SB, Mainali A, Schwank SE, Acharya G. Maternal mental health in the time of the COVID-19 pandemic. Acta Obstet Gynecol Scand. 2020;99(7):817-8.

27. Feng J. COVID-19 Fuels Domestic Violence In China, 2020. Available at: https://supchina.com/2020/03/24/covid-19-fuels domestic-violence-in-china/. Accessed on 24 March 2020.

28. Hermann A, Fitelson EM, Bergink V. Meeting Maternal Mental Health Needs During the COVID19 Pandemic. JAMA Psychiatry. 2021;78(2):123-4.

29. Wiradnyani LA, Khusun H, Achadi EL, Ocviyanti D, Shankar AH. Role of family support and women's knowledge on pregnancy-related risks in adherence to maternal iron-folic acid supplementation in Indonesia. Public Health Nutr. 2016;19(15):2818-28.

30. Chen H, Guo J, Wang C, Luo F, Yu X, Zhang W, et al. Clinical characteristics and intrauterine vertical transmission potential of COVID-19 infection in nine pregnant women: a retrospective review of medical records. Lancet. 2020;395(10226):809-15.

31. Nodoushan RJ, Alimoradi H, Nazari M. Spiritual Health and Stress in Pregnant Women During the Covid-19 Pandemic. SN Compr Clin Med. 2020; 16:1-7.

32. Dong $\mathrm{Y}, \mathrm{Mo} \mathrm{X}, \mathrm{Hu} \mathrm{Y}$, et al. Epidemiological characteristics of 2143 pediatric patients with 2019 coronavirus disease in China. Pediatrics. 2020;1-30.

33. Li S, Wang Y, Xue J, Zhao N, Zhu T. The Impact of COVID-19 Epidemic Declaration on Psychological Consequences: A Study on Active Weibo Users. Int J Environ Res Public Health. 2020;17(6):2032.

Cite this article as: Chakraborty B. Did COVID-19 challenges psychological resilience of pregnant women? an evidence-based review with recommendation. Int J Community Med Public Health $2021 ; 8: 3172-9$. 